\title{
Research into Dendro-Acoustic Properties of Intro- duced Clones' Wood as Material for Manufacturing Musical Instruments
}

\author{
Vladimir Ilyich Fedyukov ${ }^{1 *}$, Ekaterina Yurevna Saldaeva ${ }^{1}$, Maria Sergeyevna Chernova ${ }^{1}$, \\ Vasilii Yuryevich Chernov ${ }^{1}$
}

(1) Volga State University of Technology, Department of Standardization, Certification and Merchandizing, Lenin Sq., 3, RU-424 000 Yoshkar-Ola, Russia

*Correspondence: e-mail: fiv48@mail.ru

\begin{abstract}
Citation: FEDYUKOV VI, SALDAEVA EY, CHERNOVA MS, CHERNOV VY 2019 Research into Dendro-Acoustic Properties of Introduced Clones' Wood as Material for Manufacturing Musical Instruments. South-east Eur for 10 (2): 173-179. DOI: https://doi.org/10.15177/seefor.19-18

Received: 17 Jun 2019; Revised: 2 Aug 2019; Accepted: 11 Sep 2019; Published online: 3 Nov 2019
\end{abstract}

\begin{abstract}
Background and Purpose: Studies of the physical-mechanical and acoustic properties of maple wood as a potential material for musical instruments manufacturing are extremely scarce. Related to this, dendro-acoustic studies of maples introduced by geographic origin are of great practical importance in order to create target plantations with predicted technical quality of wood.

Materials and Methods: Maples from abroad introduced by geographic origin into the Botanical Garden of the Volga State University of Technology of the Republic of Mari El of Russia were used for the research. For comparison, the Norway maple of local origin (Acer platanoides L.) was selected. The studies were carried out by the frequency-amplitude method for determining Young's dynamic modulus and the acoustic constant of sound emission according to the criterion of academician N. Andreyev.

Results: It was revealed that there are differences in the density and dendroacoustic indices of maple wood of local origin and maple trees introduced by geographic origin. Norway maple (Acer platanoides L.) turned out to possess the largest acoustic constant characterizing the resonant properties of wood. Introduced maple trees, plane-tree maple (Acer pseudoplatanus L.) and sugar maple (Acer saccharinum L.) are only slightly inferior in terms of this indicator.

Conclusions: The dendroacoustic properties of maple wood are generally much lower than that of resonant spruce. Consequently, the acoustic role of maple wood in the back plates of the violin and other string instruments is completely different than that of the top plate made from the resonant material of coniferous species. To reveal this difference in more detail, comparative studies and dendroacoustic identification of maple wood in blanks and musical instruments with different levels of acoustic characteristics are necessary.
\end{abstract}

Keywords: introduced maples, maple wood, density, modulus of elasticity, speed of sound, acoustic constant

\section{INTRODUCTION}

It is known that maple wood plays no less important role in achieving special sound of a musical instrument designed of two levels of plates - top and back - than that of spruce resonant wood. A good confirmation of this is the fact that the mannerism of Amati, Guarneri, Stradivarius and other old Italian masters in different years can be determined by the macro-structure of wood used for making violins, not only for the top plate, from spruce, but also for the back plate, mainly from maple [1].

In addition to the production of musical instruments, wood of this species is widely used in other industries where material with beautiful texture, high density, wear resistance, hardness and strength is required in manufacturing machine parts, special types of veneer, parquet, furniture and so on. Therefore, today high-quality maple wood, along with spruce resonant wood, is in deficit and is very expensive timber worldwide. 
Russia is not an exception, where after the harsh winter of 1978 there was a massive drying of maples, even in mixed stands, and the operational stands of this breed were sharply reduced. Their natural recovery is far from the best. For example, in the forests of the Republic of Mari El, where these studies were carried out, maple trees are preserved only in mixed stands on an area of only about 2000 hectares, and the share of maples does not exceed $10 \%$ in these plantations.

Meanwhile, when in 1910 a large expedition of forestry scientists from Germany and Russia took place along Volga, it found large areas of resonant spruce and maple stands in this area. First, these riches were exported to Germany in large quantities, where it was decided to build workshops for the production of violins, guslias and other musical instruments from local wood in Kozmodemyansk [2].

One of the main ways of preserving and increasing the timber reserves of this valuable species in the forests of Russia today is to create target plantations with predictable technical quality of maple wood, including those introduced by geographic origin. In solving this problem, the search for the best genetic taxa plays a special role. It should be done by performing complex studies of the physical-mechanical and acoustic properties of standing wood by non-destructive methods, i.e. without cutting trees.

\section{MATERIALS AND METHODS}

The object of this study were maples introduced by geographic origin on the territory of the Botanical Garden of the Volga State University of Technology (VSUT), which are characterized by the following dendrometric indicators (Table 1).

For comparison, local maple (Acer platanoides L.) was selected.
The type of habitat conditions is $\mathrm{C}_{2}$; the soil is soddy-low podzolic, clay loam, fresh. Planting was carried out without prior preparation of the soil. The seedlings were brought from the State Botanical Garden of the USSR Academy of Sciences (Moscow), where special plantations of these maples introduced by geographic origin had been previously established. The seedlings were placed in groups for each introduced species at a distance sufficient for growth and development.

The material for research in the form of side branches was taken strictly from the south side of the trees with the help of a special tool - pruner (Figure 1).

Experimental cuttings from 3.0 to $7.0 \mathrm{~mm}$ in diameter and from 70.0 to $100.0 \mathrm{~mm}$ long without bark were made on these branches under laboratory conditions and kept until they reached moisture content of wood of $W=8 \pm 2 \%$. The cuttings were taken from the third and subsequent (of at least 2) segments from the end of the branches, i.e. the relatively soft wood of the last two years of growth was excluded (Figure 2). Immediately before the study, test cuttings were straightened with a special clamp.

\section{Theoretical Background and Research Method}

Today, in many countries, the main criterion of 'musicality' of the material under study is the acoustic constant of sound radiation, K, proposed by Andreyev [3]:

$$
K=\sqrt{\frac{E_{d y n}}{\rho^{3}}}, \int \quad E_{d y n}=C^{2} \cdot \rho
$$

where $E_{d y n}$ is dynamic modulus of elasticity, $\mathrm{MPa} ; \mathrm{C}$ is the speed of sound, $\mathrm{m} \cdot \mathrm{s}^{-1}$; and $\rho$ is density, $\mathrm{kg} \cdot \mathrm{m}^{-3}$.

It is important to keep in mind that research requires manufacturing of standard samples in the form of bars $20 \times 20 \mathrm{~mm}$ in width and thickness across and $300 \mathrm{~mm}$ in

TABLE 1. Dendrometric characteristics (age, height, diameter at breast height - DBH) of maple trees.

\begin{tabular}{lccc}
\multicolumn{1}{c}{ Taxon name } & Age (years) & Height (m) & DBH (cm) \\
\hline $\begin{array}{l}\text { Field maple } \\
\text { (Acer campestre L.) }\end{array}$ & 35 & 8.7 & 7.8 \\
$\begin{array}{l}\text { Plane-tree maple-sycamore } \\
\text { (Acer pseudoplatanus L.) }\end{array}$ & 35 & 3.6 & 3.8 \\
$\begin{array}{l}\text { Manchus maple } \\
\text { (Acer tegmentosum Maxim) }\end{array}$ & 60 & 18.1 & 14.7 \\
$\begin{array}{l}\text { Subspecies Ginnala Tatarian maple } \\
\text { (Acer tataricum subsp. Ginnala Maxim) }\end{array}$ & 70 & 8.7 & 6.0 \\
$\begin{array}{l}\text { Sugar maple } \\
\text { (Acer saccharinum L.) }\end{array}$ & 44 & 15.3 & 12.6 \\
$\begin{array}{l}\text { Red maple } \\
\text { (Acer rubrum L.) }\end{array}$ & & & 10.8 \\
$\begin{array}{l}\text { Ash-leaved maple } \\
\text { (Acer negundo L.) }\end{array}$ & 30 & 13.1 & 11.0 \\
$\begin{array}{l}\text { Norway maple } \\
\text { (Acer platanoides L.) }\end{array}$ & 57 & 12.3 & 13.4 \\
\hline
\end{tabular}




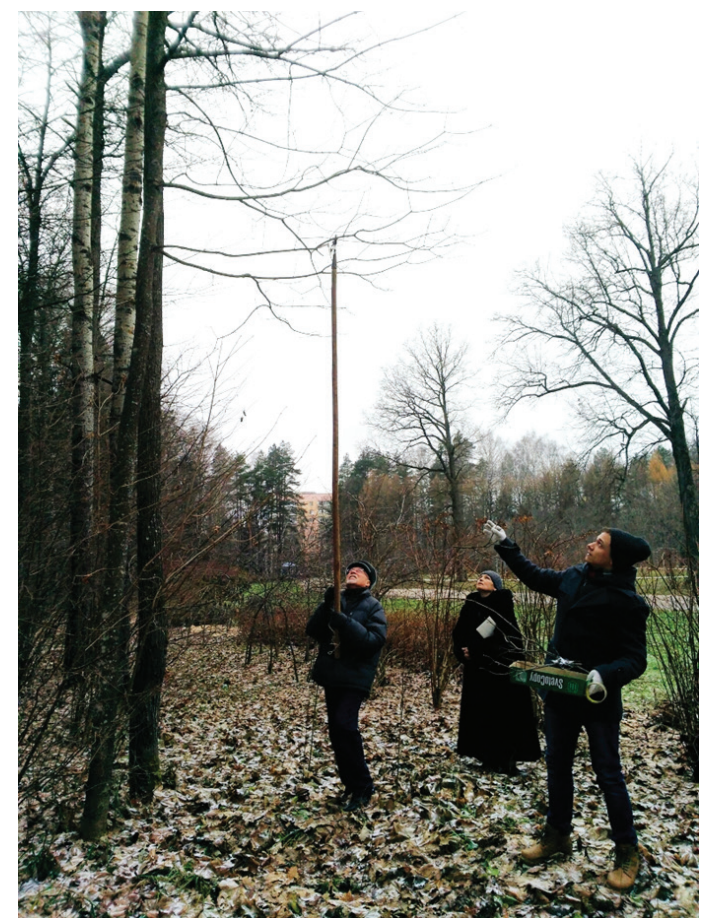

FIGURE 1. Taking research material from growing maple trees.

length along the wood fibers. It is clear that it is impossible to manufacture such samples without cutting a tree. Therefore, this destructive method is more suitable for the selection of resonant wood from harvested timber in woodworking shops than in the forest.

Diagnostics of resonance properties of standing timber should be carried out by a non-destructive vibration method by determining eigenfrequency (resonant frequency) on samples in the form of radial-transverse cores taken by a hollow drill from the stem part of the tree [4]. Such tool is widely used by foresters in determining the age of a growing tree.

In recent years, scientific works have appeared abroad, confirming the existence of a relationship between the modulus of elasticity of the wood of the branches and the stem [5-8]. In other words, the modulus of elasticity of the wood of the branches is an objective indicator to be used as a criterion in a non-destructive method for assessing the technical properties of wood of a tree stem.

Since $E_{d y n}$ according to Equation 1 is one of the main characteristics of the resonance material, in dendroacoustic studies of tree species with hard wood or young stock with small stem diameter, where it is difficult or impossible to take radially transverse cores, cuttings can be used as experimental samples made from side branches of growing trees even at an early age.

Acoustic constant $\mathrm{K}$, according to the results of vibration measurements of cylindrical shape samples (cuttings), is determined by Equation 2 [9]:

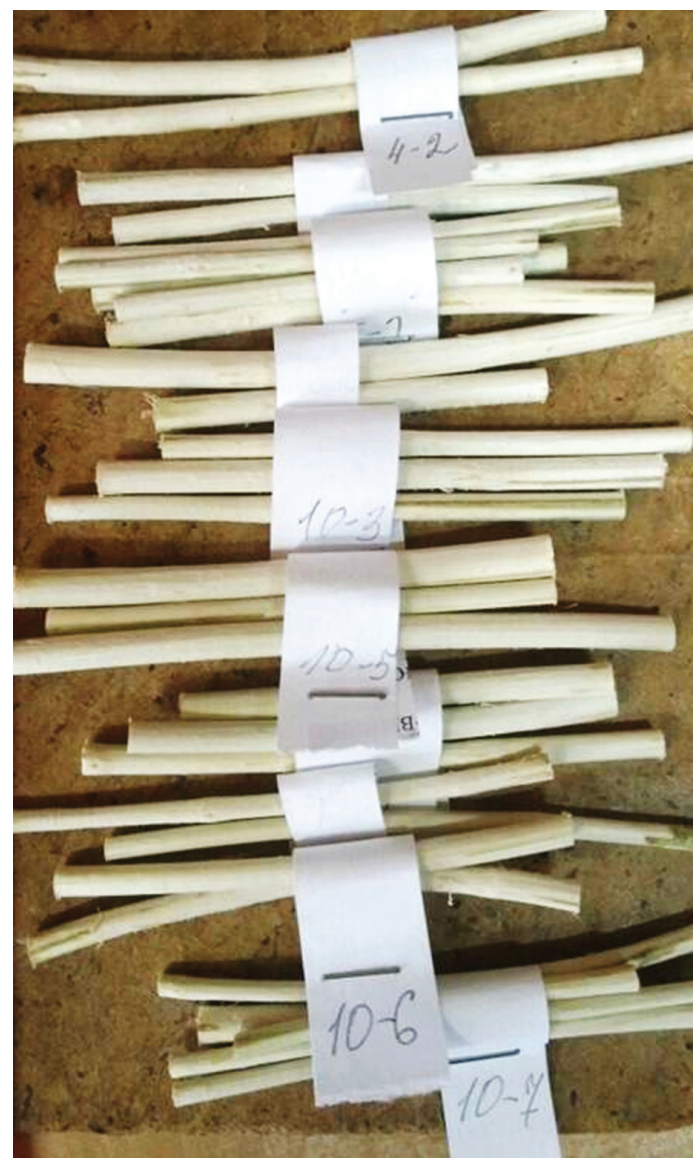

FIGURE 2. Test cuttings for experimenting.

$$
K=\sqrt{0.328 \frac{m \cdot l^{3} \cdot f^{2}}{\rho^{3} \cdot\left(m_{k} \cdot l^{2}+\frac{m \cdot l^{2}}{3}\right)} \cdot 10^{-6}}
$$

where $\mathrm{K}$ is acoustic constant, $\mathrm{m}^{4} \cdot \mathrm{kg}^{-1} \cdot \mathrm{s}^{-1}$; $\mathrm{f}$ is resonant (eigen-) frequency, $\mathrm{Hz} ; \ell$ is sample working length, $\mathrm{m} ; \rho$ is sample density, $\mathrm{kg} \cdot \mathrm{m}^{-3} ; \mathrm{m}_{\mathrm{k}}$ is mass of a ferromagnetic 'cap' on the sample (Figure 3,4 ), $\mathrm{kg} ; \mathrm{m}$ is mass of sample working part, $\mathrm{kg}$; and $\mathrm{d}$ is sample mean diameter, $\mathrm{m}$.

The threshold value for resonant wood in the longitudinal direction along the fibers is $\mathrm{K} \geq 12.0 \mathrm{~m}^{4} \cdot \mathrm{kg}^{-1} \cdot \mathrm{s}^{-1}$, and for transverse radial measurements it is $\mathrm{K} \geq 3.5 \mathrm{~m}^{4} \cdot \mathrm{kg}^{-1} \cdot \mathrm{s}^{-1}$. However, it should be borne in mind that this indicator is set for conifers (spruce, caucasian fir and cedar); the speed of sound along the fibers in their wood reaches an average of 5500.0-6000.0 m: $\mathrm{s}^{-1}[10]$.

Hardwood with a more complex anatomical structure has different parametres, which is confirmed by other studies $[10,11]$. It is more convenient to determine the density of wood in samples of arbitrary shape, cuttings, by the method of buoyancy [12]. 
Vibration studies were carried out using a hardwaresoftware complex. Figure 3 shows a general view of a fragment of the device with a cantilever mount of a prototype, and the complete schematic diagram is shown in Figure 4.

Previously, this method was used in non-destructive diagnostics of the resonant properties of standing spruce. It is protected by a patent of the Russian Federation for invention [13] and was widely tested in other works [4, 9, 14]. Therefore, without going into a detailed presentation, we only noted the essence of dendroacoustic measurements.

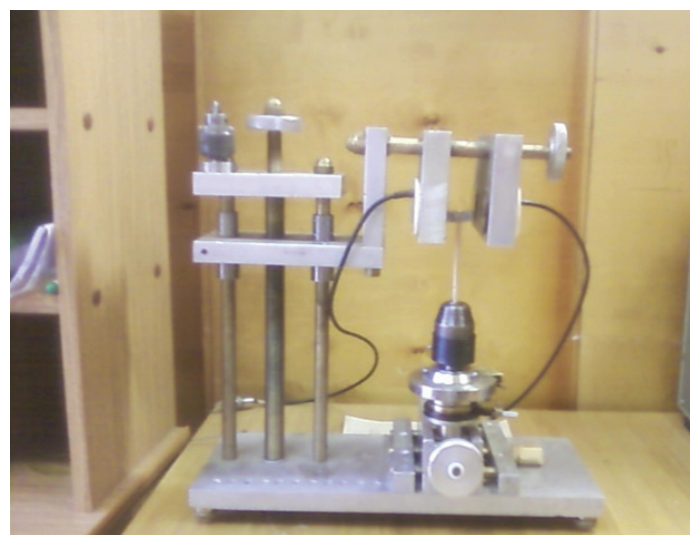

FIGURE 3. General view of the device with a cantilever mount prototype.

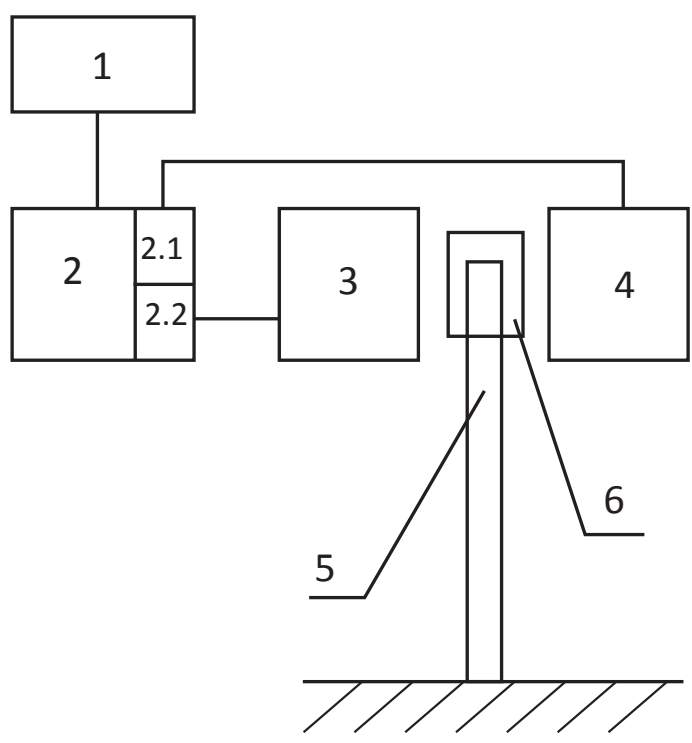

FIGURE 4. Principle diagram of hardware-software complex for defining frequency -amplitude properties of wood: 1 monitor; 2 - computer, containing: 2.1 - sound board input, 2.2 - sound board output; 3 - TK-67-H-type vibrator; 4 - TK67H-type transducer; 5 - sample; 6 - ferromagnetic 'cap'.
The harmonic signal comes from full-duplex sound card (2) of the computer system unit to electromagnetic sensor (vibrator) (3) exciting transverse oscillations of vertically installed sample (5) by means of soft iron 'cap' (6) with an internal diameter adjusted to the diameter of the sample (cutting). After fixing, the signal taken by the electromagnetic sensor is fed to the input of the full-duplex sound card. The corresponding histogram is displayed on monitor screen (1), and the sample eigenfrequency (resonant frequency) is determined by the maximum peak.

For non-standard samples, in this case the cuttings, it is advisable to determine the basic density of wood through the identification of buoyancy.

Basic wood density is known to be expressed as

$$
\rho_{\mathrm{b}}=m_{\mathrm{o}} / V_{\max }
$$

where $\rho_{b}$ is basic wood density, $\mathrm{g} \cdot \mathrm{cm}^{-3} ; \mathrm{m}_{\mathrm{o}}$ is mass of absolutely dry sample, $g$; $V_{\max }$ is volume at humidity equal to or higher than the saturation limit of the wood cell walls, $\mathrm{cm}^{3}$.

With the basic wood density of maple wood given it is possible to calculate its standard density at $12 \%$ humidity according to the following equation (4) [10]:

$$
\rho_{12}=\rho_{\mathrm{b}} / 0.823
$$

where $\rho_{12}$ is standard density at $12 \%$ humidity, $\mathrm{g} \cdot \mathrm{cm}^{-3}$.

The method of determining wood density by measuring the buoyancy force is given in the monograph by Poluboyarinov [12] and is as follows (Figure 5).

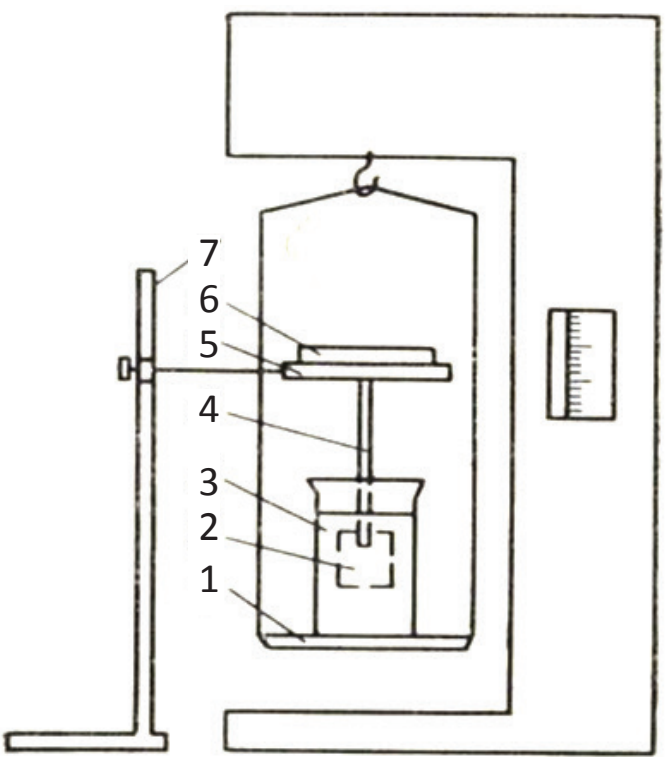

FIGURE 5. Diagram of the device for determining wood density by measuring buoyancy: 1 - weighing pan; 2 sample; 3 - vessel with water; 4 - needle; 5 - ring; 6 - holder; 7 - tripod. 
A vessel with water (3) is placed on the weighing pan (1). Ring (5) fixed to tripod (7) is placed above the vessel. The ring serves as a support for the holder (6), having needle (4) with its end doused into water. In this position, the vessel with water is weighed. After that, the holder is removed and the sample (2), previously held in water, is placed onto the needle to determine its volume. After immersing the sample, a second report is taken. An additional load on the weighing pan is created by overcoming the buoyant force acting on the sample (Archimedes' Law) and is numerically equal (if we take the density of water equal to 1 ) to the sample volume. Consequently, the difference in readings on the scale gives the desired volume in cubic centimeters.

The sample mass in absolutely dry condition will be determined by weighing on an electronic scale after drying at $103^{\circ} \mathrm{C}$ for about 10 hours.

\section{RESULTS AND DISCUSSION}

Table 2 shows a comparative analysis of the results obtained by the vibration method on samples of Norway maple and taxa.

For better clarity, the results of the research are given in the form of graphic images (Figure 6-8).

In recent years, the activity of foreign scientists in the field of studying acoustic and elastic properties of wood has increased [5-7, 15-21]. In some countries, exploratory physical-acoustic studies have begun to identify the possibility of using not only spruce wood, but also other species for manufacturing musical instruments, especially string instruments (violin, classical guitar, etc.). For this purpose, fruit wood was studied, namely, sweet cherry, cherry, pear, crab apple, walnut and prune. The results

TABLE 2. Dendroacoustic characteristics of maple wood.

\begin{tabular}{|c|c|c|c|c|c|}
\hline Taxon name & Valid & $\begin{array}{c}\rho \\
\left(\mathrm{kg} \cdot \mathrm{m}^{3}\right)\end{array}$ & $\underset{(\mathrm{Hz})}{f_{\mathrm{o}}}$ & $\begin{array}{l}E_{\mathrm{dyn}} \\
(\mathrm{MPa})\end{array}$ & $\begin{array}{c}\mathbf{K} \\
\left(\mathrm{m}^{4} \cdot \mathrm{kg}^{-1} \cdot \mathrm{s}^{-1}\right)\end{array}$ \\
\hline $\begin{array}{l}\text { Field maple } \\
\text { (Acer campestre L.) }\end{array}$ & 48 & 535.05 & 188.75 & 2027.15 & 1.5 \\
\hline $\begin{array}{l}\text { Plane-tree maple-sycamore } \\
\text { (Acer pseudoplatanus L.) }\end{array}$ & $-\ll-$ & 553.5 & 562 & 21635.6 & 2.5 \\
\hline $\begin{array}{l}\text { Manchus maple } \\
\text { (Acer tegmentosum Maxim) }\end{array}$ & $-\ll-$ & 599.8 & 169 & 22067.2 & 0.6 \\
\hline $\begin{array}{l}\text { Subspecies Ginnala Tatarian maple (Acer tataricum } \\
\text { subsp. Ginnala Maxim) }\end{array}$ & $-\ll-$ & 513.4 & 149 & 16572.2 & 1.1 \\
\hline $\begin{array}{l}\text { Sugar maple } \\
\text { (Acer saccharinum L.) }\end{array}$ & $-\ll-$ & 492.2 & 328 & 28556.6 & 2.3 \\
\hline $\begin{array}{l}\text { Red maple } \\
\text { (Acer rubrum L.) }\end{array}$ & $-\ll-$ & 615.2 & 228 & 35131.3 & 1.2 \\
\hline $\begin{array}{l}\text { Ash-leaved maple } \\
\text { (Acer negundo L.) }\end{array}$ & $-\ll-$ & 493.2 & 228.0 & 37341.1 & 3.1 \\
\hline $\begin{array}{l}\text { Norway maple } \\
\text { (Acer platanoides L.) }\end{array}$ & $-\ll-$ & 522.5 & 365.7 & 28362.2 & 2.6 \\
\hline
\end{tabular}

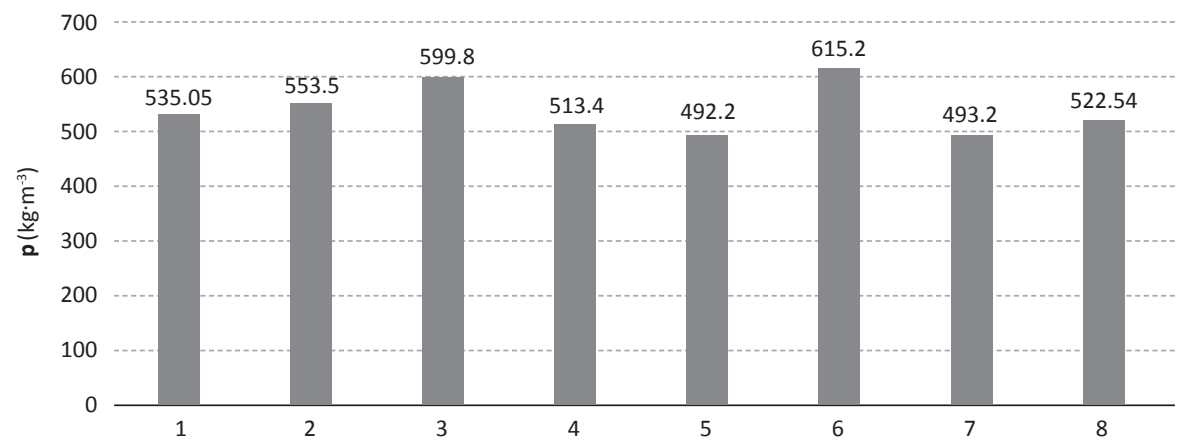

FIGURE 6. Distribution of the average density of maple wood by taxa: 1 - field maple (Acer campestre L.); 2 - plane-tree maplesycamore (Acer pseudoplatanus L.); 3 - Manchus maple (Acer tegmentosum Maxim); 4 - subspecies Ginnala Tatarian maple (Acer tataricum subsp. Ginnala Maxim); 5 - sugar maple (Acer saccharinum L.); 6 - red maple (Acer rubrum L.); 7 - ash-leaved maple (Acer negundo L.); 8 - Norway maple (Acer platanoides L.). 


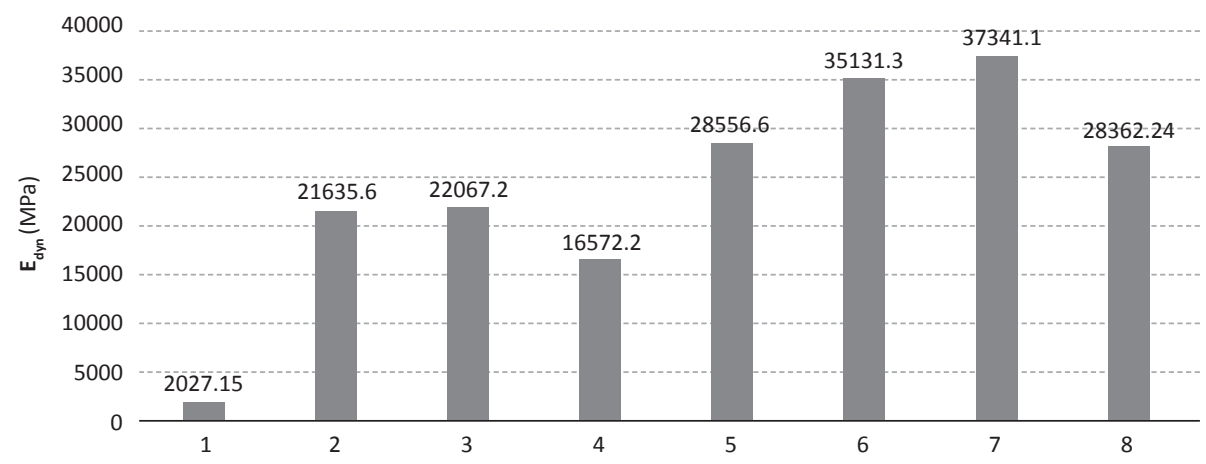

FIGURE 7. Taxon distribution of the average dynamic modulus of elasticity $\left(E_{d y n}\right)$ of maple wood by frequency-amplitude method (taxon numbering corresponds to the keys in Figure 6).

4

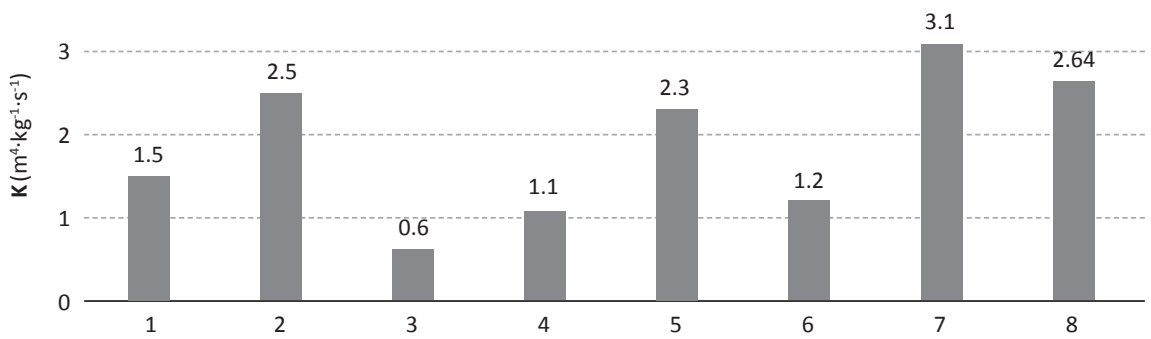

FIGURE 8. Taxon distribution of the average value of acoustic constant (K) of maple wood by the frequency-amplitude method (taxon numbering corresponds to the keys in Figure 6).

obtained showed that the wood of these species does not meet the requirements for the top plate acoustic and other physical-mechanical properties, but can be used in manufacturing separate parts of musical instruments. Moreover, sweet cherry wood is of greatest practical interest because it is close to maple by the value of acoustic constant, i.e. it is suitable for making the back plate. Thanks to this combination, the original sound of a musical instrument is achieved [22].

It is important to note that maple wood, especially with 'birdseye' fiddle mottle, along with spruce resonant wood, plays a major role in forming acoustic properties of musical instruments' sounds [1]. Such wood texture is more often formed in sugar maple (Acer saccharinum L.), but it can also occur in other species of maple: field maple (Acer campestre L. and Acer campestre), red maple (Acer rubrum L.), Manchurian maple (Acer mandschuricum L.), Norway maple (Acer platanoides L.) and plane-tree maple-sycamore (Acer pseudoplatanus L.).

Consequently, to study the dendroacoustic properties of maple wood in general, and especially depending on the genetic and geographic origin is of practical importance.

In this aspect, the scientific work on identifying the quality of maple wood for manufacturing the back plate of a violin is of great interest [11]. The paper shows that the highest quality wood for this purpose should have high density (about $600 \mathrm{rg} \cdot \mathrm{m}^{-3}$ ), low acoustic constant of sound propagation (about $6.7 \mathrm{~m}^{4} \cdot \mathrm{kg}^{-1} \cdot \mathrm{s}^{-1}$ ) and sound speed from 3800 up to $4600 \mathrm{~m} \cdot \mathrm{s}^{-1}$. Although these indicators have not yet been accepted in wide practice as a criterion for selecting material in the production of musical instruments, we will analyze our research results in comparison with these data.

In terms of density, red maple (Acer rubrum L.) and Manchus maple (Acer tegmentosum Maxim) mostly correspond with the data mentioned above; wood density of these species is about 615.0 and 600.0 and $\mathrm{rg} \cdot \mathrm{m}^{-3}$, correspondingly.

Sugar maple (Acer saccharinum L.) and ash-leaved maple (Acer negundo L.) have lower density of wood of 492.2 and $493.2 \mathrm{rg} \cdot \mathrm{m}^{-3}$, correspondingly.

Judging by the acoustic constant of sound propagation, the wood of Manchus maple is even more different from not only red maple (only 0.6 vs. $1.2 \mathrm{~m}^{4} \cdot \mathrm{kg}^{-1} \cdot \mathrm{s}^{-1}$ ), but also from all other species of maple for which the acoustic constant of sound propagation is in the range of $1.1-3.1 \mathrm{~m}^{4} \cdot \mathrm{kg}^{-1} \cdot \mathrm{s}^{-1}$, this indicator being the highest for ash-leaved maple (Acer negundo L.) and Norway maple (Acer platanoides L.), 3.1 and $2.6 \mathrm{~m}^{4} \cdot \mathrm{kg}^{-1} \cdot \mathrm{s}^{-1}$, correspondingly.

According to the maple of local origin, Norway maple (Acer platanoides L.), compared to the introduced species, has average density $\left(522.5 \mathrm{rg} \cdot \mathrm{m}^{-3}\right)$, but relatively high acoustic constant of sound propagation $\left(2.6 \mathrm{~m}^{4} \cdot \mathrm{kg}^{-1} \cdot \mathrm{s}^{-1}\right)$. 
In general, all studied trees have a relatively low acoustic constant of sound propagation. This is explained by the fact that the object for non-destructive research were lateral branches having the indicator of acoustic constant of sound propagation lower than the trunk of the tree [9].

\section{CONCLUSIONS}

Thus, the maples introduced by geographical origin under the conditions of the Volga region of Russia differ in density and dendroacoustic characteristics of wood. According to scientific criteria [11], in the forest conditions of the Republic of Mari El, the wood of red maple (Acer rubrum L.) and Manchus maple (Acer tegmentosum Maxim) introduced by geographic origin is more appropriate as the material for making the back plate of the violin. Local maple is somewhat inferior in wood quality for this purpose. However, the results of the work presented are only scientific and educational in nature and cannot pretend to the development of practical recommendations for the target selection and cultivation of one or another kind of maple in these conditions. To solve this problem, it is necessary to monitor the growth of these trees and supplement comprehensive studies by combining the efforts of forestry scientists, wood scientists, physicists, acousticians, and musical instruments production specialists.

\section{REFERENCES}

1. VITACHEK EF 1964 Essays on the history of the manufacturing string instruments Moscow, Music, $341 \mathrm{p}$

2. SANUKOV NK 1994 The only one in Russia. Mari El: Yesterday, Today, Tomorrow. 5-6: 82-84

3. ANDREYEV NN 1938 On the tree for musical instruments. Collection of works, CMSRL ML, 1:11-18.

4. FEDYUKOV VI 2016 Resonant spruce: selection from standing trees, cultivation, target use: Scientific publication. Yoshkar-Ola, VSUT, $256 \mathrm{p}$

5. HSU LC-Y, CHAUHAN S, KING N, LINDSTRÖM H 2003 Modulus of elasticity of stemwood vs branchwood in 7 -year-old Pinus radiata families. N Z J Forest Sci 33 (1): 35-46

6. LINDSTRÖM H, HARRIS P, NAKADA R 2002 Methods for measuring stiffness of young trees. Holz als Roh-und Werkstoff 60: 165-167

7. MAMDY C, ROZENBERG P, BASTION JC 1995 NonDistructive assessment modulus of elastivity in genetic field tests in France: 20 IUERO World :mgr., Tampere, 7-11 Aug. 1995. IAWA J 1: 16

8. LINDSTRÖM H, NAKADA R, RALSTON J 2003 Cell wall structure and wood properties determined by acoustics - a selective review. Holz als Roh-und Werkstoff 61 (5): 321335

9. SALDAYEVA YY 2015 Development of a method for early non-destructive diagnostics of the resonant properties of standing spruce. PhD Thesis Tech. Voronezh, Russia

10. UGOLEV BN 2001 Wood science with basic concepts of timber merchandizing. Moscow State Forestry University, Moscow, Russia, $340 \mathrm{p}$

11. WEGST UGK 2006 Wood for sound. Am J Bot 93 (10): 14391448. DOI: https://doi.org/10.3732/ajb.93.10.1439

12. POLUBOYARINOV OI 1976 Wood density. Forest industry, Moscow, Russia, $159 \mathrm{p}$

13. Pat. 2439561 RF. IPC G 01 N 33/46. Method for early diagnosis of resonant properties of wood. Fedyukov VI, Saldayeva EY, Vasenev AL, No 2439561 C2; appl. 26.032009; publ. 10.01.2012; Bul. of invent. 2012. No 1.
14. FEDYUKOV V, SALDAYEVA E, CHERNOVA M 2017 Different ways of elastic modulus comparative study to predict resonant properties of standing spruce wood. Wood Res 62 (4): $607-614$

15. BUCUR V 2006 Acoustics of Wood. Springer Verlag Berlin Heidelberg, Germany, 393 p. DOI: https://doi. org/10.1007/3-540-30594-7

16. BLSKOVA G, BRDAROV N 2003 Sounding wood acoustic characteristics studies. In: Collection of scientific reports at 50th anniversary of the Forest Engineering Institute: Woodworking and furniture production section. Sofia, Bulgaria, pp 49-53

17. CULIK M 2013 Drevo a jeho vyuzitie vo vyrobe hudobnych nastrojov. Technicka univerzita vo Zvolene, Zvolen, Slovakia, $93 \mathrm{p}$

18. DANIHELOVA A 2004 Relevant Physical Acoustics of Spruce Wood as a Material for Musical Instruments. In: Proceedings of the 8th World Conference on Timber Engineering WCTE 2004, Lahti, Finland, pp 491-494

19. DANIHELOVA A, CULIK M 2013 Netradicne vyuzitie jarabiny vtacej na vyrobu konstrukcnych sucasti violy. In: Noise and vibration in practice, Proceedings of the 18th International Acoustic Conference. Slovenska technicka univerzita v Bratislave, Bratislava, Slovakia, pp 27-30

20. NAKAMURA N 1997 Development of measuring Yong's modulus of planting stock. Journal of the Japanese Forestry Society 79(1): 43-48. DOI: https://doi.org/10.11519/ jifs1953.79.1 43

21. YOSHIHARA H 2012 Off-axis Young's modulus and offaxis shear modulus of wood measured by flexural tests. Holzforchung 66 (2): 207-213

22. HALACHAN P, SPISIAK D 2014 Phisical-acoustical characteristics of chosen fruitwoods. In: Proceedings of the 5th International Symposium of Regional Coordination Council on Wood Sci."The Structure, Quality, Properties of Wood-2014, pp 22-25 
